\title{
Diskursus Kredibilitas dan Pertimbangan Etika Pers dalam Proses Produksi Berita Viral \#Justiceforaudrey di Liputan 6 Siang SCTV
}

\author{
1 Fran Celino Octhanto Bata, 2 Umaimah Wahid \\ 1Mahasiswa Magister Ilmu Komunikasi Universitas Budi Luhur, \\ ${ }_{2}$ Pengajar Magister Ilmu Komunikasi Universitas Budi Luhur \\ Email :11871600084@student.budiluhur.ac.id*;2 umaimah.wahid@budiluhur.ac.id \\ * corresponding author
}

\begin{tabular}{ll}
\hline ARTICLE INFO & ABSTRACT \\
\hline & Viral events on social media are often made into the news. One of the social media \\
viral events that made the news in mid-2019 was \#JusticeforAudrey. Allegations \\
of violence against Audrey made headlines in all mass media, including on Liputan \\
6 Siang SCTV. During April 2019, projections related to Audrey's coverage were \\
submitted by producers every day. The news values that is the basis for \\
determining the feasibility of an event to become news is no longer the priority of \\
producers. This research paradigm is critical with a qualitative approach and uses \\
the Fairclough Critical Discourse Analysis method. Theory of Political Economy \\
Vincent Mosco explains the practice of viral news values is the practice of \\
commodification of content and audiences. Viral social media events are \\
considered attractive to internet users and expected to attract tv viewers. The \\
practice of viral social media news is the commodification of content. Meanwhile, \\
in the commodification of audiences, television news viewers in the form of rating \\
\& share are used as sales to advertisers, which in turn become an economic \\
advantage for media corporations.
\end{tabular}

\section{PENDAHULUAN}

Peristiwa yang telah viral di media sosial sering kali diangkat menjadi materi berita oleh media massa. Misalnya peristiwa Justice for Audrey yang viral di media sosial, langsung menjadi materi berita di media massa, salah satunya di Liputan 6 SCTV. Bermula dari petisi yang diunggah oleh Fachira Anindy di situs change.org pada tanggal 9 April 2019, tagar Justice for Audrey langsung menjadi trending topic di twitter Indonesia. Tagar Justice for Audrey merupakan aksi solidaritas untuk siswi SMP di Kota Pontianak (Kalimantan Barat), yang diduga menjadi korban kekerasan dan pengeroyokan yang dilakukan oleh 12 pelajar tingkat SMA. Sejumlah dukungan pun meluncur dalam bentuk penandatanganan petisi di situs change.org, dan dalam waktu kurang dari 24 jam setelah diunggah Fachira Anindy, petisi Justice for Audrey telah ditandatangani lebih dari tiga juta orang.

Viralnya petisi Justice for Audrey diakibatkan oleh perubahan pola komunikasi karena perkembangan teknologi komunikasi berbasis internet. Penelitian mengenai perubahan pola komunikasi di era digital pernah dilakukan oleh Ditha Prasanti (2016), dimana dari hasil penelitiannya didapatkan pola komunikasi secara face to face mulai hilang dan digantikan dengan komunikasi melalui media daring. Media sosial adalah salah satu media daring yang mulai menjadi saluran komunikasi utama antar manusia.

Tagar Justice for Audrey setelah viral di media sosial twitter, dan berkembang menjadi berita di media massa. Berita didefinisikan sebagai segala sesuatu yang hangat dan menarik perhatian khalayak. Berita berisi laporan faktadan ide terbaru yang dipilih oleh staf redaksi suatu 
media massa (Tamburaka, 2013). Justice for Audrey juga menjadi berita di tayangan Liputan 6 Siang SCTV. Sebelum menjadi berita, materi liputan Justice for Audrey diminta oleh salah seorang produser. Peristiwa dugaan kekerasan terhadap Audrey terjadi pada 29 Maret 2018. Materi liputan Audrey telah dikirim Koresponden SCTV-IVM Pontianak pada 8 April 2019. Dalam materi liputan yang dikirimkan tersebut, dituliskan bahwa Audrey mengalami luka di sekitar daerah kewanitaan akibat kekerasan yang dialami.

Materi liputan Audrey yang telah dikirim pada 8 April 2019 tidak menarik perhatian produser Liputan 6 SCTV untuk ditayangkan. Setelah menjadi viral di media sosial keesokan harinya, baru materi liputan Justice for Audrey diminta oleh produser. Seharusnya suatu peristiwa dipilih menjadi berita setelah memenuhi nilai berita atau kriteria layak berita. Nilai berita tersebut adalah timeliness and immediacy, proximity, conflict, eminence and prominence, concequence and impact, dan human interest (Junaedi, 2015).

Perhatian redaksi Liputan 6 SCTV terhadap peristiwa dugaan pengeroyokan Audrey cukup besar ditandai dengan permintaan update berita selama beberapa hari dalam rapat proyeksi. Perencanaan liputan di Liputan 6 SCTV dilakukan setiap sore hari melalui rapat proyeksi. Dalam rapat proyeksi, setiap anggota rapat yang terdiri dari kepala produksi berita, produser eksekutif, produser, koordinator liputan Jakarta, koordinator liputan daerah dan koordinator kameraman, mengajukan usulan liputan berita keesokan harinya (Fachruddin, 2016). Rapat redaksi yang digelar dari tanggal 10 April 2019 hingga 14 April 2019, muncul proyeksi liputan update Audrey.

Porsi perhatian terhadap liputan Audrey yang besar tersebut, berbanding terbalik dengan hasil visum yang mematahkan dugaan terjadinya kekerasan. Diumumkan oleh Kapolresta Pontianak, Kombes M. Anwar Nasir pada 10 April 2019, hasil visum tidak ditemukan adanya bekas luka pada tubuh Audrey. Bahkan luka di sekitar kewanitaan Audrey yang viral di media sosial, tidak ditemukan bekas luka robek atau memar.

Meski hasil visum yang membantah terjadinya kekerasan fisik terhadap Audrey telah keluar pada 10 April 2019, namun hingga beberapa hari setelahnya, proyeksi liputan Audrey masih diusulkan oleh produser Liputan 6 Siang SCTV. Peneliti menduga proyeksi liputan dibuat karena masih viral dan menjadi topik hangat di media sosial. Pertimbangan nilai berita yang seharusnya menjadi dasar pemilihan suatu peristiwa untuk diangkat menjadi materi tayangan berita tidak menjadipertimbangan utama.

Berdasarkan penjelasan latar belakang tersebut, maka penulis menetapkan rumusan masalah dalam penelitian ini adalah bagaimanakah bentuk praktek ekonomi politik dalam pemberitaan tagar Justice for Audrey di Liputan 6 Siang SCTV? Untuk mendapat menjawab rumusan masalah tersebut, maka dalam penelitian ini penulis menggunakan metode analisis wacana kritis Norman Fairclough. Paradigma kritis dipilih peneliti karena terjadi ketidaksesuaian antara praktek produksi berita dengan teori jurnalistik. Metode analisis wacana kritis Fairclough dipilih karena akan dapat mengupas secara jelas proses di 3 tingkatan, yaitu teks, praktek kewacanaan dan praktek sosial yang dilakukan oleh redaksi Liputan 6 Siang SCTV. Tujuan dari penelitian ini adalah untuk membongkar bagaimana praktisi media bekerja dalam mengemas berita yang ditayangkan.

\section{KERANGKA TEORITIS}

\subsection{Komunikasi Massa dan Televisi}

Media massa, terutama televisi dengan karakteristik audiovisual, memiliki kekuatan besar dalam memengaruhi opini publik. McQuail menjelaskan tentang kekuatan media massa sesungguhnya adalah menarik dan mengarahkan perhatian publik, membujuk (opini dan kepercayaan), memengaruhi sikap, membentuk pengertian realitas, memberi status dan legitimasi, dan memberi informasi secara cepat dan luas (McQuail, 2011). 
Terdapat tiga pihak yang memiliki pengaruh paling besar dalam organisasi media massa yaitu pihak manajemen, profesional media, dan pendukung teknik atau teknologi. Ketiga pihak ini berada di tengah medan pertarungan dimana mereka harus membuat keputusan di tengah berbagai hambatan, batasan, dan tuntutan serta berbagai upaya untuk memasukan pengaruh dan kekuasaan ke dalam organisasi media (Morrisan, 2017). Semua media massa merupakan perpanjangan komunikasi manusia yang secara konvensional (ideal) berfungsi menerangkan, mendidik, menghibur dan membujuk (Mulyana, 2008).

\subsection{Analisis Wacana Kritis Norman Fairclough}

Wacana adalah gagasan umum di mana bahasa ditata menurut pola-pola berbeda yang diikuti oleh ujaran para pengguna bahasa sesuai dengan domain kehidupan sosial yang berbeda (Jorgensen, 2007). Mengacu definisi Jorgensen tersebut, maka analisis wacana dapat diartikan sebagai analisis atas pola-pola tersebut. Van Dijk menjelaskan analisis wacana kritis sebagai penelitian analitik wacana yang terutama mempelajari cara penyalahgunaan, dominasi, dan ketidaksetaraan kekuatan sosial yang berlaku, direproduksi, dan ditentang oleh teks dan pembicaraan dalam konteks sosial dan politik (Fauzan, 2014).

Norman Fairclough memandang analisa wacana secara kritis sebagai bentuk pemakaian bahasa dalam tuturan dan tulisan sebagai bentuk praktik sosial yang menyebabkan sebuah hubungan dialektis di antara peristiwa diskursif tertentu dengan situasi, institusi, dan struktur sosial yang membentuknya (Eriyanto, 2012). Praktik produksi teks bisa jadi menampilkan efek ideologi: ia dapat memproduksi dan mereproduksi hubungan kekuasaan yang tidak imbang antara kelas sosial, laki-laki dan wanita, kelompok mayoritas dan minoritas melalui mana perbedaan itu direpresentasikan dalam posisi sosial yang ditampilkan.

Dalam menganalisa wacana secara kritis, Norman Fairclough (Jorgensen, 2007) menggunakan tiga dimensi, yaitu:

1. Dimensi Tekstual, meliputi representasi, relasi, dan identitas. Teks dibongkar secara linguistis untuk melihat bagaimana suatu realitas ditampilkan atau dibentuk hingga merepresentasikan ideologi tertentu. Bagaimana penulis mengonstruksi hubungannya dengan pembaca (baik secara formal atau informal, tertutup atau terbuka). Bagaimana suatu identitas ditampilkan (identitas penulis dan pembaca),

2. Dimensi Praktik Kewacanaan atau Produksi Teks, meliputi proses produksi teks. Proses produksi teks mengacu pada pembuat teks, pengalaman, pengetahuan, kebiasaan, lingkungan sosial, kondisi, keadaan, konteks, dan sebagainya yang dekat pada diri atau dalam si pembuat teks. Peneliti tidak membahas proses konsumsi teks karena yang menjadi fokus penelitian ini adalah proses produksi program berita televisi.

3. Dimensi Praktik Sosial, berhubungan dengan konteks diluar teks, seperti konteks situasi, konteks yang berhubungan dengan masyarakat, atau budaya, dan politik tertentu yang berpengaruh terhadap kehadiran teks.

\subsection{Ekonomi Politik Vincent Mosco}

Vincent Mosco (2009) mendefinisikan ekonomi politik media sebagai studi tentang hubungan sosial dan kekuatan yang saling berhubungan didalamnya yang membentuk produksi, distribusi, dan konsumsi dari sumber daya, termasuk komunikasi. Ekonomi politik media mempelajari bagaimana semua perusahaan media bekerja. Media pada dasarnya beroperasi dengan ideologi kapitalis dimana kepetingan pemodal dari pemilik media mempengaruhi isi dari media tersebut (Sumanri, 2011).

Mosco menjabarkan ekonomi politik suatu perusahaan media dalam 3 proses yaitu komodifikasi, spasialisasi, dan strukturasi. Dalam penelitian ini, proses yang terjadi adalah komodifikasi, yaitu proses transformasi sebuah produk atau jasa agar memiliki nilai tambah untuk ditukarkan atau dipasarkan. Dalam konteks media, produk dan jasa yang dikomodifikasi adalah isi, khalayak, dan tenaga kerja. Komodifikasi isi adalah perubahan sekumpulan informasi 
dan data menjadi produk pesan yang dapat dipasarkan. Isi adalah komoditas pertama yang dijual pada khalayak atau audience. Komodifikasi khalayak adalah perubahan peran khalayak sebagai konsumen media menjadi konsumen pengiklan. Dalam komodifikasi khalayak ini ada kerjasama antara media dan pengiklan sehingga dapat menjual khalayak dalam bentuk rating kepada pengiklan. Komodifikasi khalayak sendiri dinilai sebagai bagian integral dari komodifikasi isi untuk mendukung pemasukan bagi operasional dan keuntungan bisnis dari perusahaan media (Choiriyati, 2017). Komodifikasi tenaga kerja adalah perubahan keahlian dan jam kerja pegawai media menjadi karya (Mosco, 2009).

Dionni Ditya Perdana (2017) dalam penelitiannya yang berjudul Komodifikasi Dalam Tayangan Televisi (Kajian Terhadap Program Indonesia Idol 2014) menjelaskan bahwa televisi swasta di Indonesia memiliki kecenderungan mencari pemasukan iklan untuk menjaga keberlangsungan perusahaannya. Kecenderungan tersebut sejalan dengan konsep utama bisnis media televisi yaitu mencapai nilai rating dan share yang tinggi untuk ditawarkan pada pengiklan. Perusahaan iklan memilih program acara yang banyak ditonton pemirsa dan jumlah penonton tersebut diwakili oleh nilai rating dan share. Untuk mengejar peroleha rating dan share setinggi mungkin, dilakukan komodifikasi pada setiap sisi. Program acara menampilkan berbagai sensasi dan dikemas secara spektakuler untuk menarik minat masyarakat untuk menonton.

Penelitian lainnya yang berjudul Komodifikasi Cermin Retak Agama di Televisi (Yusuf, 2016) juga menjelaskan bahwa korporasi televisi menomorsatukan laba finansial melalui rating dan share untuk mengukur keberhasilan sebuah program acara televisi. Keuntungan finansial bahkan juga dikejar melalui program acara bernuasa keagamaan karena memiliki daya tarik pemirsa yang tinggi.

\section{METODE PENELITIAN}

Penelitian ini menggunakan paradigma kritis, dimana paradigma kritis bertujuan mengubah hubungan sosial dengan mengungkapkan sumber yang mendasari kontrol sosial, hubungan kekuasaan, dan ketidaksetaraan (Neuman, 2014). Paradigma kritis dipilih karena peneliti akan mengkritisi praktek keseharian yang dilakukan oleh media televisi dalam memproduksi berita.

Penelitian ini menggunakan pendekatan kualitatif. Peneliti melakukan observasi proses produksi berita Liputan 6 Siang SCTV dan mewawancarai sejumlah orang yang terlibat dalam proses produksi. Penelitian kualitatif adalah penelitian yang digunakan untuk meneliti obyek alamiah dimana peneliti bertindak sebagai instrumen kunci (Sugiyono, 2016). Sebagai instrumen kunci peneliti akan menemukan fakta dan data dengan berpartisipasi dengan obyek penelitian dan juga dikumpulkan secara triangulasi atau gabungan. Analisis data bersifat induktif berdasarkan temuan lapangan yang disusun menjadi hipotesis atau teori.

Peneliti menggunakan Analisis Wacana Kritis Norman Fairclough sebagai metode dalam penelitian ini. Norman Fairclough memandang analisa wacana secara kritis sebagai bentuk pemakaian bahasa dalam tuturan dan tulisan sebagai bentuk praktik sosial yang menyebabkan sebuah hubungan dialektis di antara peristiwa diskursif tertentu dengan situasi, institusi, dan struktur sosial yang membentuknya (Eriyanto, 2012:). Dalam penelitian ini, peneliti akan menganalisi wacana Justice for Audrey yang diangkat dan ditayangkan dalam Liputan 6 Siang SCTV. Peneliti akan menganlisa pemakaian bahasa dalam tayangan berita dan mencari hubungan dialektis dengan situasi dan struktur sosial.

Peneliti akan menggunakan metode analisa 3 dimensi wacana kritis Fairclough, yaitu dimensi tekstual, praktik kewacanaan dan praktik sosial (Jorgensen, 2007). Dalam dimensi tekstual, teks akan dibongkar secara linguistik untuk melihat bagaimana suatu realitas ditampilkan atau dibentuk hingga merepresentasikan ideologi tertentu, bagaimana penulis mengonstruksi hubungannya dengan pembaca (baik secara formal atau informal, tertutup atau terbuka), dan bagaimana suatu identitas ditampilkan (identitas penulis dan pembaca). Dimensi 
kedua yaitu dimensi praktik kewacanaan atau produksi teks yang meliputi proses produksi dan konsumsi teks. Dimensi yang terakhir adalah dimensi praktik sosial yang berhubungan dengan konteks diluar teks, seperti konteks situasi, konteks yang berhubungan dengan masyarakat, atau budaya, dan politik tertentu yang berpengaruh terhadap kehadiran teks.

\section{HASIL PENELITIAN DAN DISKUSI}

Pada tingkat pertama, dimensi tekstual, naskah berita yang diteliti adalah berita yang tayang pertama kali di Liputan 6 Siang tanggal 10 April 2019. Redaksi Liputan 6 Siang lebih menitikberatkan pada perkembangan proses hukum yang sedang berjalan kondisi kesehatan Audrey sebagai korban tindak kekerasan. Dua poin tersebut terlihat pada bagian Lead In berita:

POLISI MENETAPKAN TIGA ORANG TERSANGKA DARI 12 SISWI SMA YANG MENGANIAYA A-U/ SEORANG SISWI SMP/ DI PONTIANAK/ KALIMANTAN BARAT// HINGGA SIANG INI/ A-U MASIH DIRAWAT DI RUMAH SAKIT/ AKIBAT LUKA FISIK DAN TRAUMA PSIKIS YANG SERIUS//

Posisi redaksi yang membela korban kekerasan, yakni Audrey terlihat lagi pada kalimat pertama di badan berita:

SISWI SMP DIANIAYA 12 SISWI SMA SUNGGUH SADIS DAN BENGIS// PENGANIAYAAN YANG MENIMPA AU/ PELAJAR SMP DI PONTIANAK/ KALIMANTAN BARAT/ MEMBUATNYA KINI BERBARING TAK BERDAYA/ DI RUMAH SAKIT PROMEDIKA PONTIANAK//

Audrey ditampilkan sebagai sosok yang mengalami kerugian terbesar dan sangat menderita. Audrey direpresentasikan sebagai korban yang tidak berdaya yang tidak saja menderika sakit secara fisik, namun juga menderita secara psikis. Selain itu, Audrey juga direpresentasikan sebagai korban yang perlu mendapat perhatian lebih dan dukungan dalam proses hukum. Dukungan dalam proses hukum tersebut nampak dalam kalimat berikut:

POLISI DALAMI KASUS PERUNDUNGAN DAN PERIKSA SAKSI POLISI DARI POLRESTA PONTIANAK TENGAH MENYELIDIKI KASUS PERUNDUNGAN INI SECARA MENDALAM// SEMENTARA/ DARI HASIL PEMERIKSAAN DITETAPKAN TIGA ORANG TERSANGKA YANG MENJADI TERSANGKA UTAMA PENGANIAYAAN//

Meski proses hukum telah sampai pada tahap penetapan tersangka pada tiga pelaku, namun dukungan hingga tahap persidangan juga diperlihatkan. Kronologi kejadian penganiayaan yang menimpa korban. Audrey kembali direpresentasikan sebagai korban tak berdaya yang menerima penganiayaan dari para pelaku. Terlihat pada kalimat:

KORBAN MENERIMA KEKERASAN FISIK SECARA BERTUBI-TUBI//

Redaksi Liputan 6 Siang juga menambahkan potongan-potongan dukungan terhadap Audrey yang muncul dalam sejumlah media sosial. Dukungan tersebut juga datang sejumlah tokoh publik dan selebritas tanah air.

SONTAK SETELAH KISAH AU VIRAL/ MUNCUL BERAGAM DUKUNGAN/ TERMASUK SEBUAH PETISI YANG MENUNTUT KEADILAN UNTUK AU// DALAM WAKTU SINGKAT HAMPIR 2 SETENGAH JUTA ORANG TELAH MENANDATANGANI PETISI INI// MENUNJUKKAN KEPEDULIAN ANTIBULLYING ATAU ANTI PERUNDUNGAN/ DI SEJUMLAH MEDIA SOSIAL PUN/ DISUARAKAN DUKUNGAN BAGI AU/ TERMASUK OLEH PARA TOKOH PUBLIK DAN SELEBRITAS TANAH AIR//

Secara tekstual, pengemasan Audrey sebagai korban tak berdaya dimunculkan secara lebih dominan dalam badan berita. Kemudian dukungan terhadap proses hukum atas para pelaku dimunculkan. Untuk memperkuatdukungan tersebut, diangkat juga dukungan dari masyarakat, tokoh publik dan selebritas tanah air melalui potongan-potongan sejumlah media sosial.

Pada dimensi kedua, praktik kewacanaan, proses produksi program berita Liputan 6 SCTV dimulai dari perencanaan berupa Rapat Proyeksi yang digelar setiap sore hari sekitar jam 16.00 
WIB. Rapat Proyeksi adalah rapat yang membahas usulan liputan untuk program berita keesokan harinya. Rapat Proyeksi tersebut dihadiri oleh kepala produksi berita, produser eksekutif, produser, koordinator liputan jakarta, koordinator liputan daerah dan koordinator kameraman (Fachruddin, 2016).

Materi pembahasan dalam Rapat Proyeksi adalah perencanaan peliputan yang akan dilakukan pada keesokan harinya. Perencanaan dibuat berdasarkan rancangan materi berita yang dibuat oleh Produser dan diminta untuk diliput oleh tim peliputan. Selain itu, tim peliputan dapat mengajukan sejumlah agenda kegiatan yang akan berlangsung keesokan harinya yang layak tayang dan menjadi bahan pertimbangan Produser untuk dimasukkan dalam rundown program berita.

Sesuai dengan teori yang diajukan oleh Fachruddin (2016) bahwa proses produksi program berita televisi dimulai dari rapat proyeksi yang dihadiri oleh anggota redaksi televisi tersebut. Walaupun pada prakteknya, perencanaan proses produksi program berita tidak selalu dimulai pada rapat proyeksi. Di luar rapat proyeksi, perencanaan berupa permintaan liputan dapat diajukan oleh produser program berita. Seperti yang terjadi pada program berita Liputan 6 SCTV, terkadang permintaan liputan diberikan oleh produser kepada korlip dan korda di luar rapat proyeksi. Para produser dapat mengajukan permintaan liputan sesudah rapat selesai digelar dan bahkan pada tengah malam atau dini hari, produser dapat mengajukan permintaan liputan berita. Contohnya adalah permintaan liputan Audrey yang ditanyakan kepada koordinator liputan daerah atau korda pada sekitar jam 23.00 tanggal 9 April 2019.

Audrey adalah seorang siswi SMP di Kota Pontianak, Kalimantan Barat, yang diduga mengalami perisakan dan pengeroyokan oleh 12 siswi tingkat SMA. Pada saat permintaan liputan Audrey diajukan tersebut, materi liputan Audrey dari Pontianak sudah ada sejak sehari sebelumnya, yaitu pada tanggal 8 April 2019. Koresponden SCTV-IVM wilayah Pontianak telah mengirimkan materi liputan tersebut dan hingga 9 April 2019 petang, materi liputan tersebut belum tayang di program berita SCTV.

Peneliti menjadi tertarik dengan kenyataan bahwa materi liputan Audrey telah tersedia sejak 8 April 2019 sore dan permintaan liputan baru ditanyakan pada 9 April 2019 malam. Ini berarti materi liputan Audrey lolos dari perhatian produser program Liputan 6 Malam pada tanggal 8 April 2019, Liputan 6 pagi, siang, dan Terkini pada keesokan harinya. Redaksi SCTV-IVM memiliki sistem kerja listing atau pendaftaran materi liputan ke dalam sistem komputer bernama Inews yang diterapkan dengan harapan memperkecil lolosnya materi liputan yang telah masuk dari pantauan produser. Sistem listing ini selalu diterapkan oleh korda dan korlip yang sedang bertugas. Materi liputan yang telah dikirim oleh tim peliputan di lapangan, akan di-listing oleh korda dan korlip. Materi liputan dalam listing tersebut akan dipisah dalam 2 kelompok yaitu materi yang belum tayang dan yang sudah tayang.

Viralnya sebuah peristiwa di media sosial menjadi dorongan utama dalam pemilihan materi liputan Audrey sebagai bahan tayangan berita di Liputan 6 Siang SCTV. Praktek pemilihan materi viral media sosial menjadi bahan berita dapat dijelaskan melalui dimensi ketiga Analisis Wacana Kritis Fairclough, yaitu dimensi praktik sosial. Dimensi ini berhubungan dengan konteks diluar teks, seperti konteks situasi, konteks yang berhubungan dengan masyarakat, atau budaya, dan politik tertentu yang berpengaruh terhadap kehadiran teks. Dalam penelitian ini, teks yang muncul dalam bentuk berita dugaan kekerasan terhadap Audrey, dipengaruhi oleh faktor eksternal, yaitu faktor ekonomi politik media. Salah satu proses dalam teori ekonomi politik media yang diungkapkan oleh Vincent Mosco adalah komodifikasi.

Proses komodifikasi yang terjadi adalah komodifikasi khalayak atau penonton tayangan berita televisi. Dalam proses komodifikasi khalayak, terjadi perubahan peran khalayak sebagai konsumen media menjadi komoditas yang dijual kepada pengiklan. Pada komodifikasi khalayak ini, yang dikejar oleh tim produksi program berita televisi adalah rating \& share.

Sebagai laporan kinerja program yang diterima setiap hari, rating \& share menjadi pedoman dalam evaluasi dan perencanaan arah program berita yang akan ditayangkan. Redaksi Liputan 6 SCTV memiliki rapat mingguan yang secara khusus membahas rating \& share setiap program 
berita yang ditayangkan SCTV. Dalam rapat mingguan yang bernama Sidang Redaksi tersebut, setiap materi berita yang ditayangkan masing-masing program akan dibahas peringkat rating \& share.

Peringkat share \& rating menandakan posisi program acara dalam hal jumlah penonton. Setiap program acara akan dibandingan dengan program acara dari stasiun televisi lain. Bagian Penelitian dan Pengembangan SCTV yang bertugas menganalisa perolehan rating \& share selalu memerhatikan nilai dari sisi perolehan tiap program dan nilai perbandingan dengan program televisi lain. Tolak ukur keberhasilan sebuah program acara di SCTV, dalam hal ini program berita, akan ditentukan dari kemampuan untuk memperoleh target nilai rating \& share yang telah ditentukan dan apakah program berita tersebut mengungguli program acara dari televisi lainnya.

Target untuk mencapai nilai rating \& share setinggi mungkin dan mengungguli program acara televisi lain adalah upaya untuk menarik iklan sebanyak mungkin. Angka rating \& share yang tinggi menandakan jumlah penonton yang tinggi pula. Ini berarti setiap iklan yang dipasang pada program acara tersebut akan memiliki kans yang tinggi pula untuk ditonton oleh banyak orang.

Praktek mengejar rating \& share yang tinggi untuk mendapatkan iklan yang banyak dan mahal adalah praktek nyata dari apa yang telah disebutkan Vincent Mosco dalam teorinya yang bernama Ekonomi Politik Media, yaitu praktek komodifikasi khalayak. Penontn televisi atau khayalak yang dimanifestasikan dalam bentuk angka rating \& share diubah nilai gunanya untuk dijual kepada pengiklan agar tertarik memasng iklan dan menghasilkan pemasukan bagi perusahaan media.

Proses komodifikasi yang pertama kali terjadi pada media televisi adalah komodifikasi isi. Perusahaan media televisi harus terlebih dahulu menjalankan proses perubahan nilai guna data dan peristiwa menjadi berita untuk ditayangkan dalam program berita televisi. Para produser acara berita televisi akan berupaya mencari materi berita yang menarik penonton dalam jumlah yang besar untuk ditayangkan dalam programnya. Disinilah nilai berita viral muncul dan nampak dikejar oleh para produser program acara televisi.

Pengaruh positif materi peristiwa yang telah viral di media sosial terhadap rating \& share terjadi pada berita Audrey. Kinerja rating \& share berita Audrey yang ditayangkan di Liputan 6 Siang selama lebih dari dua pekan terlihat positif, menghasilkan angka yang tinggi dan tidak mengalami penurunan. Meski berdampak positif, ternyata menayangkan materi peristiwa yang telah viral di media sosial tidak selalu memberikan efek positif terhadap rating \& share tayangan berita televisi.

Bila materi viral peristiwa sesuai dengan kecenderungan selera penonton, maka efek positif rating \& share akan terjadi. Karena sebagai sebuah kecenderungan, maka kemampuan para produser mengolah sebuah materi liputan menyesuaikan diri dengan kecenderungan tersebutlah yang juga ikut berperan memberikan nilai positif terhadap rating \& share. Proses komodifikasi khalayak terjadi saat nilai rating \& share yang dicapai dijual kepada para pengiklan. Perusahaan yang memasang iklan akan mencari program-program acara televisi dengan jumlah penonton banyak. Jumlah penonton tersebut diwakili oleh nilai rating \& share.

\section{SIMPULAN}

Viral menjadi sebuah nilai berita bagi program acara berita televisi. Sebagai sebuah bagian dari industri televisi, program berita juga berorientasi pada rating \& share. Nilai rating \& share ditetapkan sebagai pencapaian yang harus direalisasikan oleh seluruh program acara televisi, tak terkecuali program berita Liputan 6 Siang. Tujuan dari pencapaian rating \& share adalah target iklan. Pemasukan iklan tersebut adalah sebuah profit yang menjadi orientasi utama dari korporasi media. Perusahaan media seharusnya tidak hanya mengejar keuntungan ekonomi, meski ekonomi itulah yang menyokong operasional perusahaan. Penayangan berita yang mengedepankan kepentingan penonton haruslah menjadi keutamaan dari kinerja media televisi. 


\section{DAFTAR PUSTAKA}

[1] Choiriyati, Wahyuni, "Manifestasi Pragmatisme Pendidikan Politik - Analisis Resepsi pada Komodifikasi Berita Selebriti Politisi," Jurnal Lugas, Vol. 1 No. 1, Hal 40-54, Juni 2017.

[2] Eddy, Gusti. (2019). Kurang dari 24 Jam Petisi Justice For Audrey Ditandatangani Lebih dari 3 Juta Orang. www.daerah.sindonews.com

[3] Eriyanto. (2012). Analisis Wacana: Pengantar Analisis Teks Media. Yogyakarta: LkiS.

[4] Fachruddin, Andi. (2016). Manajemen Pertelevisian Modern. Yogyakarta: Penerbit Andi.

[5] Fauzan, Umar, "Analisis Wacana Kritis dari Model Fairclough hingga Mills," Jurnal Pendidik, Vol. 19 No. 1, Hal 27-40, 2014.

[6] Jorgensen, Marianne W dan Louise J. Phillips. (2007). Analisis Wacana: Teori \& Metode. Yogyakarta: Pustaka Pelajar.

[7] Junaedi, Fajar. (2015). Jurnalisme Penyiaran dan Reportase Televisi. Jakarta: Prenadamedia Group.

[8] McQuail, Denis. (2011). Teori Komunikasi Massa Edisi 6. Jakarta: Salemba Humanika.

[9] Mosco, Vincent. (2009). The Political Economy of Communication 2nd Edition. London: Sage.

[10] Mulyana, Deddy. (2008). Komunikasi Massa: Kontroversi, Teori, dan Aplikasi. Bandung: Widya Padjadjaran.

[11] Neuman, W. Lawrence. (2014). Social Research Methods: Qualitative And Quantitative Approaches. London: Pearson Education Limited.

[12] Perdana, Dionni Ditya, "Komodifikasi Dalam Tayangan Televisi (Kajian Terhadap Program Indonesia Idol 2014)," Jurnal Professional, Vol 4 No 1, Hal 12-21, Juni 2017.

[13] Prasanti, Ditha, "Perubahan Media Komunikasi Dalam Pola Komunikasi Keluarga di Era Digital," Jurnal Comed, Vol 1 No 1, Hal 69-81, Agustus 2016.

[14] Sugiyono. (2016). Memahani Penelitian Kualitatif. Bandung: Alfabeta.

[15] Sumanri. "Komodifikasi Budaya Lokal dalam Televisi: Studi Wacana Kritis Komodifikasi Pangkur Jenggleng TVRI Yogyakarta,” Jurnal Komunikasi UII, Vol. 5 No. 2, Hal 171-181, April 2011.

[16] Tamburaka, Apriadi. (2013). Literasi Media, Cerdas Bermedia Khalayak Media Massa. Jakarta: Rajawali Pers.

[17] Yusuf, Muhamad Fahrudin, "Komodifikasi Cermin Retak Agama di Televisi: Perspektif Ekonomi Politik Media,” Jurnal Inject, Vol 1 No 1, Hal 25-42, Juni 2016. 